\title{
THE STATUS AND PROSPECTS OF THE ORGANIC AGRICULTURAL PRODUCTS MARKET IN UKRAINE
}

\author{
Oleksandr MASLAK ${ }^{1}$ \\ Sumy National Agrarian University, Ukraine
}

\begin{abstract}
The modern agricultural market is characterized by an increasing demand for higher quality agricultural products and food. Thus certified organic production was launched in Ukraine, which prohibited the use of chemically synthesized components, genetically modified organisms, etc., and labelling requirements for such products were established. However, experiencing both external and internal demand, the market for organic products in Ukraine is developing slowly. The subject of study focuses on the theoretical, methodological, and practical aspects of forming the organizational-economic basis of organic agricultural products market development in Ukraine. Methodology. Methodological support for the study is based on dialectical and systemic approaches to the study of economic phenomena and processes of formation of the organizational-economic bases of organic agricultural products market development. General scientific and special methods are used, in particular: methods of analogies and comparisons, systematization, statistical and economic, calculation-constructive, program-oriented. The aim of the research is to identify the state of organic agricultural products market in Ukraine and prospects of its further development. The defined goal led to the following tasks: a study of the current state of organic production in Ukraine is carried out; set of problems that hinder its further development are defined; the possible scenarios of this market are identified; prospective tasks, solution of which will contribute to the further development of the market of organic agricultural products in Ukraine, are outlined. According to the results of the conducted research, the following conclusions are made: the tendencies of organic market development in Ukraine are investigated; it is found that the lack of a proper legislative and regulatory framework, a lack of modern market infrastructure, and effective mechanisms of its functioning are holding back the further development of this market; one of the more acceptable scenarios for the society of possible development of this market is chosen; the priorities that need to be dealt with are identified. As a result, it is necessary to develop an appropriate regulatory framework and carry out its implementation according to the EU requirements, to create an efficient business environment, to provide training on the requirement of this market, to promote the dissemination of information to potential consumers and producers about the benefits of organic products for the further development of organic market in Ukraine.
\end{abstract}

Key words: organic products, organic products market, problems, perspective development.

JEL Classification: Q13, Q17, Q18

\section{Introduction}

The modern agricultural market is characterized by an increasing demand for higher quality agricultural products and food. Increasing demands for the quality of food has arisen due to the strengthening of the application of synthetic agrochemicals in the production of traditional products, environmental pollution, improving environmental awareness of the population. Thus certified organic production was launched in Ukraine, which prohibited the use of chemically synthesized components, genetically modified organisms, etc., and labelling requirements for such products were established. However, experiencing both external and internal demand, the market for organic products in Ukraine is developing slowly.
Therefore, there is a need to undertake a research and identify limiting factors in the development of this market and the priorities that require urgent solutions.

The purpose and objectives. The aim of the study is to identify the condition of the organic agricultural products market in Ukraine and prospects of its further development. The defined goal determined the formulation and the need to solve the following tasks: a study of the current state of organic production in Ukraine; the determination of problems that hinder its further development; definition of possible scenarios of the market development; the outlining of perspective tasks, solving of which will contribute to the further organic agricultural products market development in Ukraine.

\footnotetext{
Corresponding author:

${ }^{1}$ Department of Logistics and Production Management, Sumy National Agrarian University.

E-mail: almaslak@ukr.net
} 
Methodology. Methodological support for the study is based on dialectical and systemic approaches to the study of economic phenomena and processes of formation of the organizational-economic bases of organic agricultural products market development. While studying the status and trends of the domestic market for organic products, methods of analogies and comparisons, and statistical-economic, calculation and constructive methods are used. In determining the scenarios of the possible development, the priorities of this market program-oriented method are additionally applied.

Information base of research are legislative and regulatory acts, statistical and economic materials, and reports of the State Statistics Service of Ukraine, Ministry of Agrarian Policy and Food of Ukraine, Federation of Organic Movement of Ukraine, scientific information from the Internet, information bulletins and analytical surveys, scientific works of domestic and foreign researchers, results of the author's own observations.

\section{Analysis of recent research and publications}

The features of domestic and world organic products market were researched by such scientists-economists as V. Artysh, G. Bezus, N. Borodachev, H. Willer, J. Gorchakov, D. Gorshkov, T. Dudar, T. Zaichuk, N. Zinovchuk, I. Kirilenko, L. Kelcher, M. Kobets, A. Mazurova, I. Milovanov, Pisarenko, A. Rudnitskaya, A. Sahota, A. Skidan, N. Fedorov, A. Khodakovskaya, A. Khodus, K. Holger, A. Shubravska, M. Yusefi and others. However, the constant changes in the world and domestic agricultural markets, the existence of problems that hinder further development of the market of organic agricultural products in Ukraine require further research in this field.

\section{Market trends for organic products}

Traditional food dominates the domestic Ukrainian market while organic products play a secondary role. It is confirmed by the research of the Federation of Organic Movement of Ukraine and the data of the State Statistical Service of Ukraine. By the end of 2015, the cost of the domestic consumer market of organic products reached almost 18 million euros or 3 euros per capita. For comparison, total retail trade turnover of food products during this period amounted to 426,1 billion hryvnias or at the average exchange rate of the NBU 2422,87 hryvnias, for 100 Euro 17,6 billion euro. That is, the share of organic products in the domestic market of Ukraine is about 0.1 percent. However, in recent years, the consumption of organic products is constantly growing, especially in large cities. In 2010, the Ukrainian market of organic products was estimated at 2.4 million euros; in 2016 it rose to 21.2 million euros, i.e. 8.8 times, or every year, almost by 2.4 million euros (Organik v Ukrayini, 2016; Derzhstat Ukrayiny, 2016). (Fig. 1).

The filling of the internal market in organic products was due to the increase in operators in this market and expansion of certified areas required for growing organic crops. In 2002, in Ukraine there were 31 organic farms, cultivating 164,4 thousand hectares of arable land (Fig. 2) (Organik v Ukrayini, 2016).

In subsequent years, there was a gradual increase in the number of domestic organic farms and lands in their cultivation. According to the Federation of Organic Movement in Ukraine in the period from 2005 to 2015, the total number of organic farms has increased to 210 ,

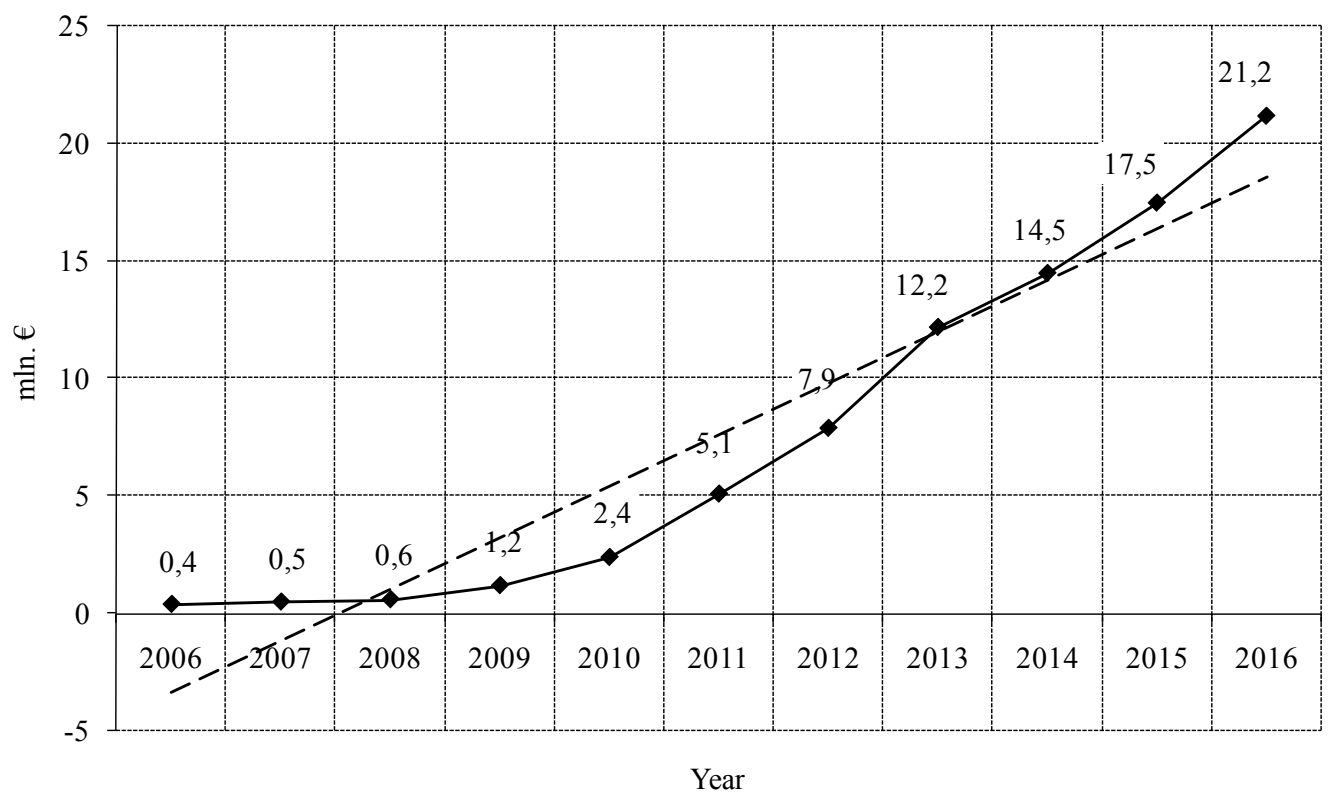

Fig. 1. Domestic consumption of organic products in Ukraine (Organik v Ukrayini, 2016) 


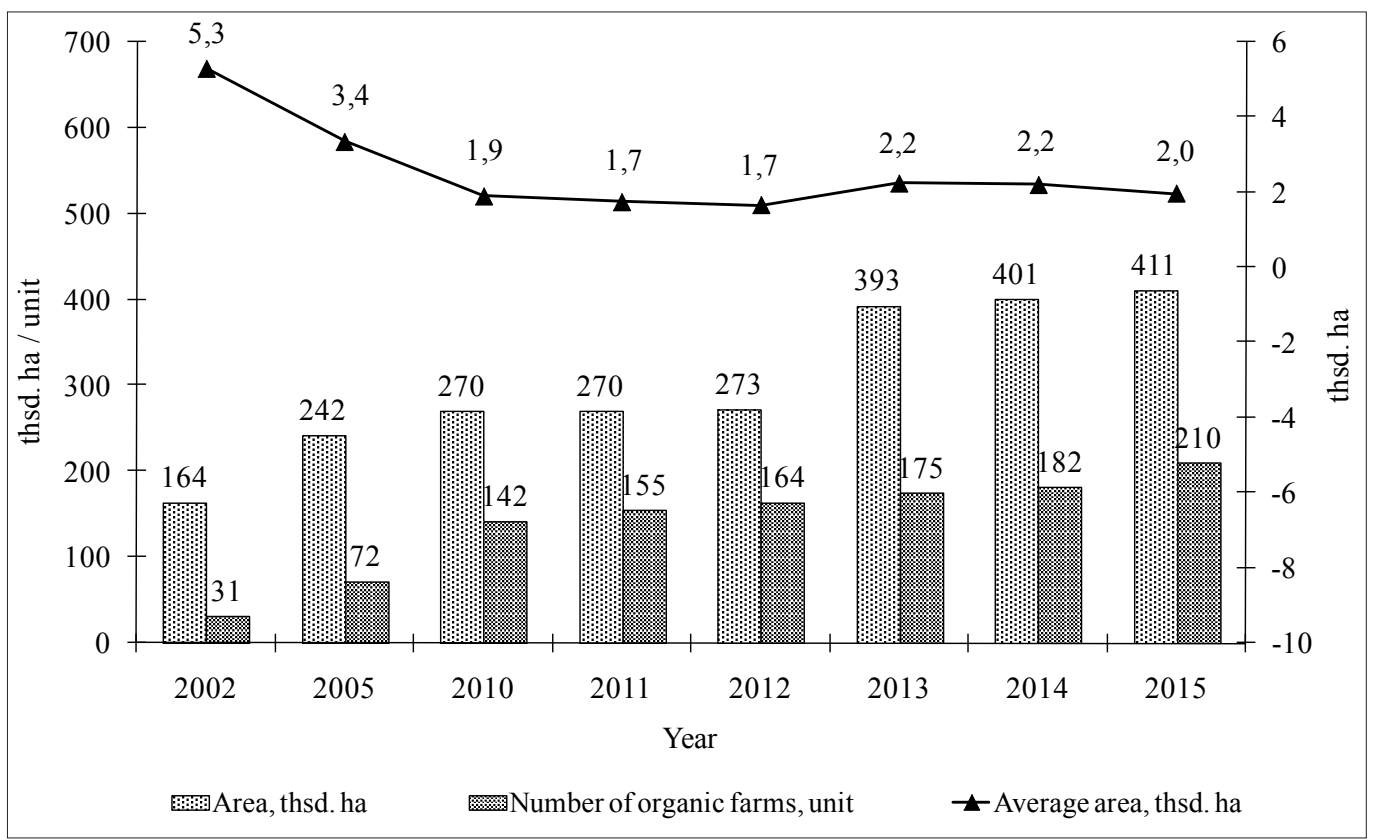

Fig. 2. Dynamics of the main indicators of organic production in Ukraine (Organik v Ukrayini, 2016)

or almost 3 times. The area of certified agricultural land in Ukraine used for the cultivation of organic products reached almost 411 thousand hectares in 2015. In comparison with 2010, it is by 1.7 times bigger amount. Overall, the share of Ukrainian certified organic area is about $1 \%$ of the total agricultural land. This fact gave Ukraine an opportunity (with the availability of certified organic acreage of arable land) to take first place in the Eastern European region and to strengthen its position in the top twenty of the world's leading countries in organic production (Organik v Ukrayini, 2016).

The size of organic farms varies from tens of hectares to several thousand hectares. Now the average size of a certified organic farm in Ukraine is less than 2 thousand hectares, which is significantly more compared to similar households in other countries. However, with the spread of labour-intensive areas of organic products production, small farms began to develop. It is confirmed by trends in the development of organic producers over the last ten years. In 2005, the average size of organic farms amounted to 3.4 thousand hectares while in 20132014 it decreased to 2.2 thousand, in 2015 to 2.0 ha. In future, growth in the number of organic producers is expected at the expense of small and medium farms (Organik v Ukrayini, 2016). Grain crops, legumes, and oilseeds occupy the largest share in the structure of the organic cultivation of agricultural products (Fig. 3).

Vegetables, fruits, herbs, grapes, melons are grown in smaller areas. Besides, at the beginning of 2016, 540 thousand hectares of wild plants were certified in Ukraine (Organik v Ukrayini, 2016).

Among the organic products vegetables and fruits, juices, cereals, flour, milk and milk products, meat and meat products are in greatest demand among domestic

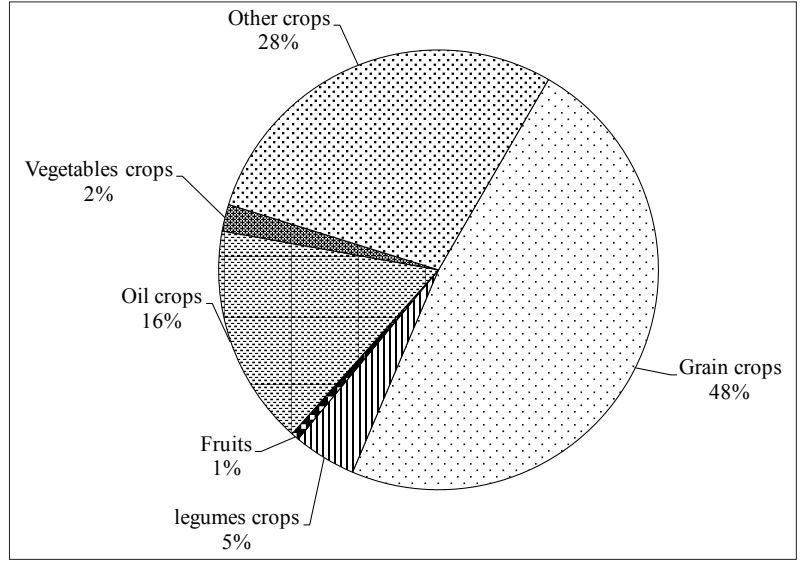

Fig. 3. Structure of organic production in Ukraine (Organik v Ukrayini, 2016)

consumers. Product sales occur through supermarket chains, specialty stores, and, more recently, via the Internet (Maslak, 2016).

Ukraine has significant potential for export of organic products. Experts estimate the annual opportunity from the sale of such products in foreign markets up to EUR 50 million. Now the main buyers of Ukrainian "organics" are Germany, Austria, Poland, Italy, France, Netherlands, Denmark, Switzerland, USA, and Canada. Demand is growing every year. Grain, oilseeds, beans, berries, fruits and wild plants are mainly exported to these countries. Besides, the range of organic products is constantly expanded and updated with sunflower and essential oils, concentrated apple juice, nuts, jams, syrups, and birch juice (Organik v Ukrayini, 2016).

However, Ukraine has not yet formed the appropriate legislative and regulatory framework that will provide for the protection of producers and consumers of 
these products, the regulation of the state. The modern infrastructure of the organic products market in Ukraine is characterized by the absence of a sufficient number of certified warehouses for storage of products, the processing enterprises for the production of organic food products, as well as intermediary structures for logging and supplying of organic products on domestic and foreign markets.

\section{Scenarios of further development}

In the future, development of Ukrainian organic products market will happen according to one of three possible options. According to the first variant, the main production of organic agricultural products will be concentrated in medium and large enterprises and sold mainly in the foreign market. The selling of raw materials will dominate in this case, not food fit for consumption. Besides, small companies interested in organic production for the domestic market will be created. The state will play a minor role in supporting the development of organic production. In such case, organic production will grow at an average annual rate of the past five years.

The second variant will increase the volume of state support of organic agriculture development and development of appropriate infrastructure; the main attention will be paid to the development of organic production in the small-scale farms, in particular, the establishment of specialized family farms and the creation of service cooperatives on their basis. Mentioned facts will contribute to filling the domestic market with organic products, will increase employment in rural areas, however, will not allow full expansion of the potential for organic production in Ukraine.

The third variant is to create the conditions to ensure the integrated development of the organic market, providing for the rational development of a competitive, diversified organic agriculture, favourable investment environment through a partnership of government and business. This will create the proper legal framework of activities harmonized with the EU legislation, will develop the processing industry and market infrastructure. The following phenomena will provide the opportunity to increase organic production, its sale in the foreign market and filling the domestic market. To solve the existing problems and determine the priorities for the further development of this segment of the market, it is better to choose the third variant as one that best meets the interests of society as a whole.

\section{Priority directions of development}

For the further development of organic production in Ukraine, it is necessary to solve individual tasks. First, to develop an appropriate regulatory framework for the state regulation of development of this market. This requires the implementation of the organic legislation of Ukraine to the European Union legislation, ensuring clear and transparent rules for the functioning of the organic sector, considering state support for such production and sales. Besides, it is necessary to create and support public authorities for the institutional development of organic agricultural products market at the national and regional levels.

Secondly, to create an efficient business environment and promote the development of organic trade. This requires the implementation of socio-economic incentives for the growth of trade volumes and quality of organic products in domestic and foreign markets, protection of consumer rights from unfair competition, and formation of a positive image of Ukraine on an international level.

Third, to provide training specialists of organic production and sales. It is necessary to develop and implement an appropriate program of training specialists in a bachelor degree, master's degree and granting of the state support for their implementation.

Fourth, to promote the dissemination of information about organic products and their promotion in the potential segment of the domestic market. This requires raising awareness about organic products among consumers and producers through the introduction of a systematic approach and state support in the sphere of communications. In addition, it is necessary to spread the knowledge among agricultural producers about the peculiarities of organic production by providing consultations, conducting seminars, conferences and other outreach events.

The solution of these tasks will contribute to the increase in the number of enterprises for the production of organic products; expansion of the certified land suitable for maintaining such a production, sales growth of organic products in the domestic and foreign markets.

\section{Conclusions}

According to the research results, the following facts should be noted. The market for organic products in Ukraine is developing slowly. It is confirmed by the annual increase in the number of operators in this market, the area of certified land suitable for the cultivation of such products. A consequence of it is the annually growing volumes of consumption of organic products in the domestic market; increasing the range of such products.

However, further development of the organic market in Ukraine is constrained due to the lack of address specific problematic issues. Among them, there is a lack of proper legislative and regulatory framework, a lack of modern market infrastructure and effective mechanisms of its functioning.

Therefore, the possible scenarios of further development of organic products market in Ukraine 
are defined; the more acceptable among them is a comprehensive development of this market in the interests of society that involves the formation of a competitive, diversified organic agriculture, favourable investment environment through a partnership of government and business. For the further development of organic market in Ukraine, it is necessary to develop an appropriate regulatory framework, to guide the implementation of the EU requirements, to create an efficient business environment, to provide training on the requirement of the market, to contribute information to potential consumers and producers about the benefits of organic products.

Further research and development should be aimed at improving the legislative base of production and circulation of organic products, the development of models and mechanisms of organic production at the regional and national level.

\section{References:}

Organik v Ukrayini (2016). [Electronic resource]. Retvitered from: http://organic.com.ua.

Struktura oborotu rozdribnoyi torgivli u 2015 roci: Dopovid (2016) - Kyiv: Derzhavna sluzhba statystyky Ukrayiny. [Electronic resource]. Retvitered from: http://www.ukrstat.gov.ua.

Maslak O.M. (2016). Formuvannya rynku organichnoyi silskogospodar`koyi produkciyi v Ukrayini. Globalni ta nacionalni problemy ekonomiky, №10. [Electronic resource]. Retvitered from: http://global-national.in.ua/issue10-2016.

\section{Александр МАСЛАК СОСТОЯНИЕ И ПЕРСПЕКТИВЫ РЫНКА ОРГАНИЧЕСКОЙ СЕЛЬСКОХОЗЯЙСТВЕННОЙ ПРОДУКЦИИ В УКРАИНЕ}

Аннотация. Современный аграрный рынок характеризуется ростом спроса на более качественную сельскохозяйственную продукцию и продовольствие. В связи с этим в Украине было начато сертифицировано производство органическойпродукции, прикоторомзапрещено использованиехимическисинтезированных составляющих, генетически модифицированных организмов и т.д., а также установлены требования к маркировке такой продукции. Вместе с тем, при наличии внешнего и внутреннего спроса, рынок органической продукциив Украинемедленно развивается.Предметом исследования избранытеоретические, методическиеипрактическиеаспектыформированияорганизационно-экономическихоснов развития рынка органической сельскохозяйственной продукции в Украине. Методологическое обеспечение исследования основывалось на диалектическом и системном подходах к изучению экономических явлений и процессов формирования организационно-экономических основ развития рынка органической сельскохозяйственной продукции. При проведении исследований использованы общенаучные и специальные методы, в частности: методы аналогий и сравнений, систематизаций, статистико-экономический, расчетно-конструктивный, программно-целевой. Цель исследования предусматривала выявление состояния рынка органической сельскохозяйственной продукции в Украине и перспектив его дальнейшего развития. Определенная цель обусловила решение следующих задач: проведение исследования современного состояния рынка органической продукции в Украине; установление проблем, которые сдерживают его развитие; определение сценария возможного развития этого рынка; обозначение перспективных задач, решение которых будет способствовать дальнейшему развитию рынка органической сельскохозяйственной продукции в Украине. По результатам проведенных исследований получены следующие выводы: исследовано тенденции развития рынка органической продукции в Украине; установлено, что отсутствие надлежащей законодательной и нормативно-правовой базы, современной рыночной инфраструктуры и действенных механизмов ее функционирования сдерживают дальнейшее развитие этого рынка; выбран один из сценариев возможного более приемлемого для общества развития этого рынка; обозначены приоритетные задачи, требующие первоочередного решения. Как результат для дальнейшего развития рынка органической продукции в Украине необходимо разработать надлежащую нормативно-правовую базу и проведения ее имплементации с требованиями ЕС, сформировать действенное бизнес-среду, обеспечить подготовку специалистов согласно с требованиями этого рынка, способствовать распространению информации для потенциальных потребителей и производителей о преимуществах органической продукции. 